УДК 664.664.6

\title{
STUDY OF THE CARBOHYDRATE-AMYLASE COMPLEX OF CEREAL FLOUR AND ITS MIXTURE WITH WHEAT
}

\author{
I. Hetman, L. Mykhonik, I. Kukharenko \\ National University of Food Technologies
}

\begin{tabular}{l}
\hline \multicolumn{1}{c}{ Key words: } \\
cereal flour, \\
wheat flour, \\
quality indicators, \\
technological properties, \\
carbohydrate-amylase \\
complex, \\
bakery products
\end{tabular}

Article history:

Received 29.05.2020

Received in revised form 20.06.2020

Accepted 15.09.2020

Corresponding author:

bilyklena@gmail.com
The article investigates the indicators of the carbohydrateamy $\neg$ lase complex of cereal flour and their mixtures with wheat the content of their own sugars, sugar-forming ability, autolytic acti $\neg$ vity, gas-forming ability, as well as technological properties that are closely related to the above-mentioned indicators.

It was found that barley and buckwheat flours have a greater amount of their own sugars, in comparison with wheat flour, which has a positive effect on gas formation in the dough at the beginning of fermentation.

The indicators of gas-forming and sugar-forming abilities of oat, barley, rice and green buckwheat flour are lower than the cor $\neg$ responding indicators of wheat flour, and mixtures are, on the contrary, higher. This is probably due to the granulometric composition of the studied types of flour, the qualitative and quantitative compo $\neg$ sition of enzymes, differences in the technology of hydrothermal treatment of cereals in preparation for grinding, which cause chan $\neg$ ges in the structure of starch grains and a decrease in the activity of enzymes. The influence of oatmeal, barley, rice and buckwheat flo $\neg$ ur on the technological properties of mixtures of wheat flour with flour of cereal crops was also established, namely, the gas-holding capacity for the specific volume of the dough and the shape-holding ability for spreading of the dough ball, which depend on the state of the carbohydrate amylase complex, determining the intensity fermentation of the dough and the content of water-soluble substances in it. It has been proven that the samples of dough from flour mix $\neg$ tures are characterized by a low rate of gas-holding capacity, in comparison with the control sample (dough from wheat flour), ho $\neg$ wever, the specific volume of dough from mixtures of wheat flour with rice and green buckwheat flour deteriorates slightly.

The investigated indicators of the carbohydrate-amylase complex and the technological properties of cereal flour and their mixtures with wheat allow their use in industry technology, while predicting the course of the technological process in bread technology using cereal flour.

DOI: $10.24263 / 2225-2916-2020-27-7$ 


\title{
ДОСЛІДЖЕННЯ ВУГЛЕВОДНО-АМІЛАЗНОГО КОМПЛЕКСУ БОРОШНА КРУП'ЯНИХ КУЛЬТУР I ЙОГО СУМІШЕЙ 3 ПШЕНИЧНИМ
}

\author{
І. А. Гетьман \\ Л. А. Михонік, канд. техн. наук \\ І. О. Кухаренко \\ Національний університет харчових технологій
}

У статті досліджено показники вуглеводно-амілазного комплексу борошна круп'яних культур та його сумішей з пшеничним - вміст власних цукрів, цукроутворювальну здатність, автолітичну активність, газоутворювальну здатність, а також технологічні властивості, які тісно пов'язані з вищезазначеними показниками. Встановлено, що більшу кількість власних цукрів, порівняно з пшеничним борошном, мають ячмінне та гречане борошно, що позитивно впливає на газоутворення в тісті на початку бродіння.

Дослідження формоутримувальної здатності показали, що більшість видів борошна можливо застосовувати в рецептурах не лише формового, але й подового хліба, адже показники розпливання кульки тіста незначно відрізнялись від контрольного зразка. Досліджені показники вуглеводно-амілазного комплексу, технологічних властивостей борошна круп'яних культур і його сумішей з пшеничним дають змогу використовувати їх в технології галузі, при цьому прогнозувати перебіг технологічних процесів у технології хліба з використанням борошна круп'яних культур.

Ключові слова: борошно круп'яних культур, пшеничне борошно, показники якоcmi, технологічні властивості, вуглеводно-амілазний комплекс, хлібобулочні вироби.

Постановка проблеми. 3 метою впливу на харчовий раціон людини через коригування хімічного складу хліба, як продукту щоденного вживання, в нашій країні і за кордоном вивчаються можливості приготування дієтичних та оздоровчих сортів хліба з додаванням продуктів переробки бобових, олійних і зернових культур, зокрема борошно і пластівці круп'яних культур. Включення в рецептури хлібних виробів борошна круп'яних культур надає їм оздоровчих і дієтичних властивостей. За різними даними, масова частка круп’яних продуктів у хлібі, збагаченому ними, складає від 10 до 40\% від загальної маси борошна в тісті, оскільки кожен з цих продуктів має специфічні особливості хімічного складу і функціональних властивостей $[1 ; 2]$.

Зважаючи на особливості кожного виду нетрадиційної для хлібопечення сировини, необхідно досліджувати їі технологічні властивості, структурно-механічні властивості тіста та перебіг мікробіологічних і біохімічних процесів у ньому для встановлення оптимальних технологічних параметрів виготовлення хліба 3 цими видами сировини [3].

Важливе значення для прогнозування якості хлібобулочних виробів мають не лише показники якості борошна та іншої сировини, зазначені в нормативній документації, а й показники, що характеризують хлібопекарські властивості борошна. Першочергове значення має стан його білково-протеїназного та вуглеводноамілазного комплексів. 
Стан вуглеводно-амілазного комплексу характеризується здатністю борошна забезпечити мікрофлору тіста цукрами в процесі бродіння та вистоювання тістових заготовок, а також реакцію меланоїдиноутворення, від якої залежить забарвлення скоринки виробів.

Оскільки борошно круп'яних культур використовується як додаткова сировина в рецептурі хлібобулочних виробів, його технологічні властивості не регламентуються нормативами галузі та вивчені недостатньо, що й зумовило необхідність їх визначення. На сьогодні обмаль даних про активність ферментів у цих видах борошна. Науковці та виробничники відмічають підвищення перебігу газоутворення в пшеничному тісті, погіршення формоутримувальної здатності тістових заготовок та зниження об'єму виробів у разі додавання борошна круп'яних культур або побічних продуктів його виробництва, що потребує пояснень [3; 4].

Зважаючи на це, існує необхідність визначити технологічні властивості найбільш поширених видів борошна круп'яних культур та їх сумішей з пшеничним 3 метою використання в технології хліба.

Мета статті: дослідження та аналіз вуглеводно-амілазного комплексу борошна круп'яних культур та його сумішей $з$ пшеничним, вивчення впливу досліджуваних видів борошна на газоутримувальну та формоутримувальну здатності тіста $з$ пшеничного борошна.

Матеріали і методи. Під час проведення досліджень було використано такі види борошна: пшеничне борошно першого сорту (контрольний зразок) ТМ «Народна»; ячмінне, рисове, вівсяне, зеленої гречки - ТМ «Органік Еко Продукт». Досліджували показники вуглеводно-амілазного комплексу, зокрема вміст власних цукрів і газоутворювальну здатність. Активність амілолітичних ферментів оцінювали непрямими методами: $\alpha$-амілази - за автолітичної активністю, $\beta$-амілази - за цукроутворювальною здатністю.

Масову частку загального цукру, зокрема моно- та дисахариди, визначали йодометричним методом [5]. Цукроутворювальну здатність борошна та борошняних сумішей визначали йодометричним методом за кількістю утвореної мальтози у водно-борошняній суспензії за методикою [6]. Автолітичну активність визначали за методом автолітичної проби (згідно з ГОСТ 27495-87) [7]. Газоутворювальну здатність борошна та борошняних сумішей визначали волюмометричним методом [6]. Формоутримувальну здатність тіста з борошняних сумішей визначали за розпливанням кульки тіста. Газоутримувальну здатність вимірювали, спостерігаючи за зміною об’єму тіста в циліндрі згідно з методикою [6].

Результати досліджень. Вуглеводно-амілазний комплекс характеризується наявністю власних цукрів, крохмалю й інших вуглеводів, активністю амілолітичних ферментів, що розщеплюють крохмаль [7].

Результати дослідження показників вуглеводно-амілазного комплексу борошна круп'яних культур порівняно з пшеничним борошном наведені в табл. 1.

Як свідчать дані табл. 1, більшу кількість власних цукрів, порівняно 3 пшеничним борошном, мають ячмінне та гречане борошно, що позитивно впливає на газоутворення в тісті на початку бродіння. Відомо, що власні цукри борошна забезпечують дозрівання тіста тільки протягом 30-60 хв, а для одержання виробів високої якості необхідно мати достатню кількість цукрів як під час дозрівання, так і остаточного вистоювання тіста, а також у період випікання. Тому важливим показником борошна $є$ його здатність утворювати цукри за допомогою ферментів 
амілолітичної дії в процесі дозрівання тіста, тобто цукроутворювальна здатність $[7 ; 8]$.

Таблиця 1. Показники вуглеводно-амілазного комплексу борошна круп'яних культур

\begin{tabular}{|c|c|c|c|c|c|}
\hline \multirow{2}{*}{ Назва показника } & \multicolumn{5}{|c|}{ Борошно } \\
\cline { 2 - 6 } & $\begin{array}{c}\text { Пшеничне } \\
\text { І сорту }\end{array}$ & $\begin{array}{c}\text { Зеленої } \\
\text { гречки }\end{array}$ & Вівсяне & Ячмінне & Рисове \\
\hline $\begin{array}{c}\text { Вміст цукрів, \% на СР } \\
\text { борошна }\end{array}$ & 0,8 & 1,3 & 0,69 & 2,08 & 0,59 \\
\hline $\begin{array}{c}\text { Цукроутворювальна } \\
\text { здатність, мг мальтози } \\
\text { на 10 г борошна }\end{array}$ & 186,0 & 77,4 & 158,0 & 175,0 & 47,0 \\
\hline $\begin{array}{c}\text { Автолітична активність, } \\
\text { \% на СР борошна }\end{array}$ & 28 & 12,8 & 15,2 & 34,9 & 8,0 \\
\hline $\begin{array}{c}\text { Сумарне газоутворення, } \\
\text { см }^{3} / 100 \text { г борошна }\end{array}$ & 1301 & 899 & 936 & 995 & 518 \\
\hline
\end{tabular}

Цукроутворювальна здатність обумовлена не тільки кількістю та активністю ферментів ( $\alpha$ - та $\beta$-амілаз), а й податливістю крохмалю до їх дії, тобто атакованістю, на що, у свою чергу, впливає ступінь механічного пошкодження крохмальних зерен під час помелу та, власне, гранулометричний склад [8]. Результати досліджень, наведені в табл. 1, свідчать про нижчу цукроутворювальну здатність борошна круп'яних культур, порівняно $з$ пшеничним, однак найменше відрізнялися вівсяне та ячмінне борошно, відповідно, 158,0 та 175,0 мг мальтози на 10 г борошна проти 186, 0 мг мальтози на 10 г борошна для пшеничного.

Отже, можна прогнозувати, що в разі виготовлення виробів на основі дріжджового тіста лише з борошна круп'яних культур без додавання пшеничного, після зброджування дріжджами власних цукрів для подальшого бродіння і реакції меланоїдиноутворення їх кількості буде недостатньо, тому до рецептури таких виробів необхідно включати цукор або патоку.

Від активності ферментів і податливості крохмалю їх дії також залежить процес автолізу (накопичення водорозчинних низькомолекулярних декстринів під дією $\alpha$-амілази). Він виражається показником автолітичної активності. За даними табл. 1 , активна $\alpha$-амілаза міститься лише в ячмінному борошні, в пшеничному борошні значення знаходиться в допустимих межах, що регламентуються галу3зю. Решта видів борошна мали низькі значення, що корелює із цукроутворювальною здатністю.

Газоутворювальна здатність $є$ комплексним показником вуглеводно-амілазного комплексу і залежить від вмісту власних цукрів у борошні та активності його амілолітичних ферментів. Для узагальнення результатів досліджували перебіг газоутворення в зразках тіста з борошна круп'яних культур протягом 5 год бродіння за методикою визначення газоутворювальної здатності пшеничного борошна. Тісто для досліджень замішували, враховуючи водопоглинальну здатність борошна круп'яних культур.

Дані сумарного газоутворення свідчать (табл. 1), що тісто з борошна круп'яних культур здатне виділити меншу кількість діоксиду вуглецю порівняно 3 пшеничним. Це свідчить про нижчу активність амілолітичних ферментів цих видів 
борошна, зокрема $\beta$-амілази. Рисове борошно характеризується найменшим значенням показника сумарного газоутворення, що корелює 3 даними вмісту цукрів у ньому та активністю амілолітичних ферментів.

Оскільки борошно круп'яних культур використовують у сумішах 3 пшеничним, виконували модельні досліди, для яких готували борошняні суміші зі співвідношенням пшеничного і круп'яного борошна - 80:20. Зазначене співвідношення борошна в сумішах зумовлене попередніми дослідженнями структурномеханічних властивостей тіста та якості виробів, проведеними на кафедрі технології хлібопекарських та кондитерських виробів НУХТ авторами статті. В ході цих досліджень було встановлено, що максимальна заміна пшеничного борошна борошном круп'яних культур, яка не призводить до суттєвого погіршення структурно-механічних властивостей тіста та якості виробів, становить 20\%.

У борошняних сумішах, як і в попередніх зразках, визначали цукроутворювальну здатність і газоутворювальну (за показником сумарного газоутворення в тісті). Отримані результати наведені в табл. 2.

Таблиця 2. Технологічні показники сумішей пшеничного борошна з борошном круп'яних культур

\begin{tabular}{|c|c|c|c|c|c|}
\hline \multirow{2}{*}{ Назва показника } & \multirow{2}{*}{$\begin{array}{c}\text { Контроль } \\
\text { (пшеничне } \\
\text { борошно } \\
\text { I сорту) }\end{array}$} & \multicolumn{4}{|c|}{$\begin{array}{c}\text { Внесено 20\% борошна круп’яних культур замість } \\
\text { маси пшеничного }\end{array}$} \\
\hline & & $\begin{array}{l}\text { Зеленої } \\
\text { гречки }\end{array}$ & Вівсяне & Ячмінне & Рисове \\
\hline $\begin{array}{c}\text { Цукроутворювальна } \\
\text { здатність, мг мальтози } \\
\text { на } 10 \text { г борошна }\end{array}$ & 180 & 197 & 215 & 265 & 263 \\
\hline $\begin{array}{l}\text { Сумарне газоутворення, } \\
\mathrm{cm}^{3} / 100 \text { г борошна }\end{array}$ & 1288 & 1512 & 1580 & 1984 & 1596 \\
\hline $\begin{array}{c}\text { Питомий об’єм тіста } \\
\text { через } 3 \text { год. бродіння, } \\
\text { см }^{3} / 100 \text { г тіста }\end{array}$ & 280 & 268 & 224 & 230 & 276 \\
\hline $\begin{array}{c}\text { Розпливання кульки } \\
\text { тіста через } 3 \text { год. } \\
\text { ферментації, мм }\end{array}$ & 124 & 143 & 96 & 105 & 125 \\
\hline
\end{tabular}

Встановлено, що суміші пшеничного борошна з борошном круп'яних культур мають вищу цукроутворювальну здатність, ніж пшеничне борошно. Ми пояснюємо ці результати дією $\beta$-амілази, яка в достатній кількості міститься в пшеничному борошні, i, відповідно, в сумішах, а також високою піддатливістю крохмалю борошна крупяних культур амілолізу завдяки гідротермічній обробці круп перед помелом та розміром крохмальних зерен. Так, за даними дослідників [9; 10], середні значення розмірів крохмальних зерен пшеничного борошна - $(12,4 \pm 1,9)$ мкм, ячмінного - $(10,9 \pm 1,15)$ мкм, вівсяного - $(7,4 \pm 0,87)$ мкм, гречаного - $(6,6 \pm 0,52)$ мкм, рисового - $(5,3 \pm 0,29)$ мкм.

Варто відмітити, що найвищий показник цукроутворювальної здатності в сумішах пшеничного борошна з ячмінним і рисовим. Для суміші з ячмінним борошном це пояснюється його високою цукроутворювальною здатністю, а для суміші 3 рисовим - найменшим розміром крохмальних зерен серед досліджуваних видів борошна.

Усі зразки тіста із сумішей мають більший показник сумарного газоутворення порівняно $з$ контролем. Найбільше сумарне газоутворення має тісто із сумі- 
шей з додаванням ячмінного та рисового борошна 1984 та 1596 см³/100 г відповідно, тоді як $з$ пшеничного борошна $1288 \mathrm{~cm}^{3} / 100$ г, що корелює 3 показником цукроутворювальної здатності сумішей.

Деякі з технологічних показників, зокрема газоутримувальна та формоутримувальна здатності тіста, значною мірою залежать від стану його вуглеводноамілазного комплексу, що обумовлює інтенсивність бродіння тіста та вміст в ньому водорозчинних речовин.

Дослідження газоутримувальної здатності показало (табл. 2), що зразки тіста 3 борошняних сумішей через 3 год бродіння мають менший питомий об'єм, ніж контрольний зразок. Це пояснюється тим, що, незважаючи на високий показник сумарного газоутворення, додавання борошна круп'яних культур замість маси пшеничного борошна зменшує вміст клейковини в тісті, тому погіршується його здатність утримувати діоксид вуглецю. Слід відмітити, що питомий об'єм тіста із сумішей пшеничного борошна $з$ рисовим та $з$ борошном зеленої гречки погіршується несуттєво. Практично всі зразки тіста з борошняних сумішей починають опадати в циліндрі через 150 хв бродіння, тоді як контрольний зразок не опадає навіть через 180 хв. Це свідчить про необхідність скорочення тривалості дозрівання та вистоювання в разі виготовлення хліба з додаванням борошна круп'яних культур.

Дослідження формоутримувальної здатності показали (табл. 2), що більшість видів борошна можливо застосовувати в рецептурах не лише формового, але й подового хліба, адже показники розпливання кульки тіста були нижчі за контрольні, або несуттєво відрізнялись. У тісті із суміші із зеленою гречкою спостерігалось значне розрідження тіста, що може бути пов'язано з високою активністю протеолітичних ферментів, тому хліб з додаванням цього виду борошна рекомендуємо виготовляти формовим.

Висновки. Показники вуглеводно-амілазного комплексу мають важливе значення при моделюванні нових рецептур хлібобулочних виробів. Вивчення цих показників у нетрадиційних видах борошна, зокрема 3 круп'яних культур, дає змогу використовувати їх у технології галузі, при цьому створювати необхідні умови приготування тіста для забезпечення належної якості хліба.

Встановлено, що борошно круп'яних культур характеризується нижчими значеннями показника сумарного газоутворення та нижчою активністю амілолітичних ферментів, порівняно з пшеничним борошном, а суміші, навпаки, мають вищі значення відповідних показників.

Заміна пшеничного борошна борошном круп'яних культур у кількості 20\% погіршує питомий об'єм тіста, незважаючи на більш інтенсивний перебіг газоутворення в ньому. Рисове борошно та борошно зеленої гречки незначно впливає на газоутримувальну здатність тіста з сумішей.

Додавання борошна круп'яних культур до пшеничного не погіршує формоутримувальної здатності тіста, крім борошна із зеленої гречки.

Подальші дослідження будуть спрямовані на вивчення активності амілолітичних ферментів борошна круп'яних культур прямими методами.

\section{ЛІТЕРАТУРА}

1. Дробот В. І. Продукты функционального назначения / В. І. Дробот, Л. А. Михонік, А. М. Грищенко // Мир продуктов. - № 9. - 2009. - С. 6-8.

2. Грищенко А. М. Технологічні властивості безглютенових видів сировини / А. М. Грищенко, В. І. Дробот // Наукові праці [Одеської національної академії харчових технологій]. 2014. - Вип. 46(1). - С. 162-166. 
3. Моргун В. О. Як поводиться композиційна суміш 3 пшеничного, гречаного, кукурудзяного борошна та пшеничних висівок при випіканні хліба / В. О Моргун, Д. О. Жигунов, О. С. Крошко // Хлібопекарська і кондитерська промисловість України. - 2004. - № 1. C. $22-23$.

4. Технологія хліба пшеничного з продуктами переробки зародків вівса та кукурудзи: монографія / С. Г. Олійник, Г. В. Степанькова, О. В. Самохвалова, О. І. Кравченко. - Харків: ХДУХТ, 2017. - $123 \mathrm{c.}$

5. Дробот В. І. Технохімічний контроль сировини та хлібобулочних і макаронних виробів / В. І. Дробот. — навчальний посібник. — К.: Кондор-Видавництво, 2015. — 958 с.

6. Дробот В. І. Лабораторний практикум з технології хлібопекарського і макаронного виробництва / В. І. Дробот. — навчальний посібник. - К.: Центр навчальної літератури, 2006. — 341 с.

7. Дробот В. І. Довідник з технології хлібопекарського виробництва / В. І. Дробот, 2-е вид., перероб. і допов. - довідник: навчальний посібник. - К.: ПрофКнига, 2019. - 580 с.

8. Лебеденко Т. Є. Технологія хлібопекарського виробництва / Т. Є. Лебеденко, Г. Ф. Пшенишнюк, Н. Ю. Соколова. - практикум: навчальний посібник. - Одеса: Освіта України, 2014. - 392 с.

9. Бутрим С. М. Морфология и размеры зерен крохмала разного ботаничепского происхождения / С. М. Бутрим, 3. А. Канарская, А. В. Канарский, В. В. Литвяк // Вестник технологического университета. — 2018. - № 3. - С.64-69.

10. Иоргачева Е. Г. Технологические свойства компонентов безглютеновых мучных смесей / Е. Г. Иоргачева, О. В. Макарова, Е. Н. Котузаки, И. В. Быстрыка // Наукові праці ОНАХТ. 2011. - Том 1, № 40. - С. 104-107.

\title{
ИССЛЕДОВАНИЕ УГЛЕВОДНО-АМИЛАЗНОГО КОМПЛЕКСА МУКИ КРУПЯНЫХ КУЛЬТУР И ЕЕ СМЕСЕЙ С ПШЕНИЧНОЙ
}

\author{
И. А. Гетьман, Л. А. Михоник, И. А. Кухаренко \\ Национальный университет пищевых технологий
}

В статье исследованы показатели углеводно-амилазного комплекса муки крупяных культур и их смесей с пшеничной - содержание собственных сахаров, сахарообразовательная способность, автолитическая активность, газообразовательная способность, а также технологические свойства, которые тесно связаны с вышеупомянутыми показателями. Установлено, что большее количество собственных сахаров, по сравнению с пшеничной мукой, имеют ячменная и гречневая мука, что положительно влияет на газообразование в тесте в начале брожения.

Исследованые показатели углеводно-амилазного комплекса, технологических свойств муки крупяных культур и их смесей с пшеничной позволяют использовать их в технологии отрасли, при этом прогнозировать ход технологического процесса в технологии хлеба с использованием муки крупяных культур. Ключевые слова: мука крупяных культур, пшеничная мука, показатели качества, технологические свойства, углеводно-амилазный комплекс, хлебобулочные изделия. 